\title{
ACCELERATED AGING AND SEEDLING FIELD EMERGENCE IN SOYBEAN
}

\author{
Reynaldo Melo Torres; Roberval Daiton Vieira*; Maristela Panobianco \\ UNESP - Depto. de Produção Vegetal, 14884-900 - Jaboticabal, SP - Brasil. \\ *Corresponding author <rdvieira@fcav.unesp.br>
}

\begin{abstract}
Information regarding the relationship between laboratory seed vigor testing and seedling field emergence is very important to estimate seed performance after sowing and help producers adopt the best procedures to improve stand establishment. The objective of the present study was to relate accelerated aging (AA) test results to soybean [Glycine max (L.) Merrill] seedling field emergence results based on data obtained over three agricultural years. The following evaluations were made: seed water content, standard germination, accelerated aging, electrical conductivity, and seedling field emergence. There was a close association between planting environmental conditions, seed physiological quality and seedling field emergence. The most accurate predictions were obtained for AA values $\geq 90 \%$, when field emergence was higher than $80 \%\left(r^{2}=0.90\right)$. Based on the results it was concluded that the AA test provided an accurate estimate of field emergence of soybean seedlings. However, as seedbed environmental conditions became less favorable, the ability of the AA test to estimate field performance significantly decreased.
\end{abstract}

Key words: Glycine max (L.) Merrill, seeds, vigor

\section{ENVELHECIMENTO ACELERADO E EMERGÊNCIA DE PLÂNTULAS DE SOJA EM CAMPO}

\begin{abstract}
RESUMO: Informações sobre a relação entre resultados de testes de vigor conduzidos em laboratório e da emergência de plântulas em campo são fundamentais para a tomada de decisões pelos produtores de sementes. O presente trabalho teve por objetivo verificar a associação entre os resultados do teste de envelhecimento acelerado e a emergência de plântulas de soja [Glycine max (L.) Merrill] em campo, em diferentes safras agrícolas e épocas de semeadura. Assim, foram efetuadas as seguintes avaliações: determinação do grau de umidade das sementes; testes de germinação, de envelhecimento acelerado e de condutividade elétrica, bem como emergência de plântulas em campo. A estimativa mais precisa do desempenho das plântulas em campo foi verificada numa faixa de valores de envelhecimento acelerado $\geq 90 \%$, estimando emergência em campo superior a $80 \%\left(r^{2}=0,90\right)$. O teste de envelhecimento acelerado permitiu avaliar a emergência de plântulas de soja em campo. No entanto, à medida que as condições ambientais do local de semeadura foram desviandose das mais adequadas, a eficiência decresceu.

Palavras-chave: Glycine Max (L.) Merrill, sementes, vigor
\end{abstract}

\section{INTRODUCTION}

Use of high quality seeds is one of the most important factors for successful crop production as the establishment of an adequate plant population in the field is necessary to achieve high productivity.

Seed physiological quality has been routinely evaluated by the standard germination test, which results are considered as reliable in terms of reproducibility and official seed inspection. However, this test does not demonstrate the same efficiency in estimating seed performance after sowing, sinceseedling field emergence results are frequently lower than those observed in laboratory germination (Marcos-Filho, 1999).

As a consequence, vigor tests have increasingly become routine for in-house seed quality control, determining physiological quality and complementing infor- mation provided by the standard germination test. The seed industry and official institutions have included these tests in their in-house quality control programs as a guarantee of the seed quality to be marketed.

One of the most popular tests used to evaluate soybean seed vigor is the accelerated aging (AA) test (Spears, 1995), which is based on increased seed deterioration after exposure to high temperature and relative humidity. This test has been standardized to evaluate the physiological potential of soybean seeds (Hampton \& TeKrony, 1995).

On the other hand, the relationship between -laboratory test results and seedling field emergence is directly influenced by environmental conditions and sowing procedures. The ability of laboratory tests to estimate the potential of seedling emergence decreases as environmental conditions become less adequate. 
Vigor tests are more adequate than standard germination tests in estimating field performance; however, no test is considered adequate under highly unfavorable environmental conditions. Egli \& TeKrony (1995) demonstrated that soybean seed lots with AA germination higher than $80 \%$ or standard germination above $95 \%$ had a high probability of producing adequate seedling emergence under a relatively high variation of environmental conditions. These investigators have also emphasized the difficulty in establishing a consistent relationship between laboratory and field results, since environmental conditions in the seedbed are highly variable and unpredictable.

Many researchers have reported significant correlation coefficients between laboratory results concerning evaluations of physiological potential (standard germination and vigor tests) and field emergence (TeKrony \& Egli, 1977; Yaklich \& Kulik, 1979). More recently, Egli \& TeKrony $(1995 ; 1996)$ found significant correlation between laboratory tests and seedling emergence. These authors also used the field emergence index to characterize seedbed conditions.

In view of the above considerations, the objective of the present study was to determine the association between accelerated aging test results and seedling field emergence in soybean sown at different times and years.

\section{MATERIAL AND METHODS}

This study was conducted at the seed laboratory and experimental farm in Jaboticabal $\left(21^{\circ} 15^{\prime} 22^{\prime \prime} \mathrm{S}\right.$, 4818'58" W, 613 m), SP, Brazil. Experiments were carried out over a period of three years (1993, 1994 and 1997), with 54, 50 and 45 soybean seed lots (cultivars: IAS-5, Foscarin-31, OCEPAR-4, FT-20, EMBRAPA-48) respectively used each year.

The following tests were performed: Seed water content - Seed water content (fresh weight basis) was determined in intact seeds in an oven at $105 \pm 3^{\circ} \mathrm{C}$ for $24 \mathrm{~h}$ in duplicate samples containing approximately 20 seeds from each lot, as recommended by Rules for Seed Testing (Brasil, 1992). Germination - Four replicates of 50 seeds each were germinated at $25^{\circ} \mathrm{C}$ in rolled paper towels moistened with water equivalent to 2.5 times the substratum weight. Seedlings were counted 5 and 8 days after sowing (Brasil, 1992). Accelerated aging - $42 \mathrm{~g}$ of seeds were placed on a wire mesh screen suspended over $40 \mathrm{~mL}$ water inside a plastic accelerated aging box (11.0 $\times 11.0 \times 3.5 \mathrm{~cm}$ ). Boxes were kept at $42^{\circ} \mathrm{C}$ and near $100 \%$ relative humidity for $48 \mathrm{~h}$. After this aging period, four replicates of 50 seeds each were submitted to the standard germination test as described above. Seedling development was evaluated five days after planting. Seed water content was determined before and after each aging period to evaluate the accuracy of the test (Hampton \& TeKrony, 1995; Marcos-Filho, 1999). Electrical con- ductivity - Four replicates of 50 seeds per lot were weighed to $0.01 \mathrm{mg}$, placed in disposable plastic cups (200 mL) containing $75 \mathrm{~mL}$ deionized water and kept in a germinator at $25^{\circ} \mathrm{C}$. After $24 \mathrm{~h}$, electrical conductivity of the imbibition solution was determined using a conductivity meter (Digimed, São Paulo, Brazil) (Hampton \& TeKrony, 1995; Vieira \& Krzyzanowski, 1999). Seedling field emergence - Three sowing times within each year investigated were studied for seedling field emergence under diverse environmental conditions. Sowing dates were October 20, November 22 and December 13 in 1993; October 29, November 14 and December 29 in 1994; and January 20, February 17 and March 10 in 1997. Four replicates of 50 treated seeds (Carboxim + Thiram - Vitavax-Thiram: $250 \mathrm{~mL} / 100 \mathrm{~kg}$ of seeds) were sown in a conventionally prepared area with $1.5 \mathrm{~m}$ long rows spaced $0.25 \mathrm{~m}$ apart and a depth of 2.5 to $3.5 \mathrm{~cm}$. Seedlings were counted once at the VC stage on the 14th day after sowing (Fehr \& Caviness, 1977).

Determination of value ranges: The range of values for the AA test and seedling field emergence were calculated based on distribution of seed lots across the three years studied. For Accelerated Aging (AA), lot ranges were determined for high quality seeds ( $\mathrm{AA} \geq 90 \%$ ), medium quality seeds $(80 \% \leq \mathrm{AA}<90 \%)$ and low quality seeds $(70 \%$ $\leq \mathrm{AA}<80 \%$ ). For seedling field emergence (FE), four value ranges were considered ( $\mathrm{FE} \geq 60,70,80$ and 90\%).

Determination of Prediction Accuracy (PA): The prediction accuracy was calculated to estimate the ability of laboratory tests to estimate field emergence according to Egli \& TeKrony (1995; 1996) as follows:

$$
P A=\frac{F E}{A A} X 100,
$$

where: PA = Prediction Accuracy (\%); FE = Number of seed lots with a specific quality level (AA $\geq 70,80$ or $90 \%$ ), in which $\mathrm{FE} \geq$ a minimum field emergence (60, 70,80 or $90 \%$ ); $\mathrm{AA}=$ Number of seed lots with specified quality level ( $\mathrm{AA} \geq 70,80$ or $90 \%$ ).

Determination of Field Emergence Index (FEI): In this index, the higher the value, the better the field conditions until FEI $=1.0$, so that FE = SG (ideal). The field emergence index for each experiment was calculated based on the procedure used by Egli \& TeKrony $(1995 ; 1996)$ according to the following equation:

$$
F E I=\frac{F E}{G} X 100,
$$

where: FEI = Field Emergence Index; FE = Mean Seedling Field Emergence of all seed lots; $\mathrm{G}=$ Mean Standard Germination of all seed lots.

Statistical Analysis: the statistical analysis was conducted using a completely randomized design, with four replicates. Simple linear correlation analyses were calcu- 
lated using the mean results of AA and other tests (standard germination, electrical conductivity and seedling field emergence) to evaluate physiological seed quality. Field Emergence Index (FEI) and Prediction Accuracy (PA) were calculated based on a second degree, polynomial regression, with their relationship being represented by curves of a higher significance level. In both regressions, linear and polynomial, the original results were transformed to arc $\sin \sqrt{x / 100}$, with the exception of electrical conductivity.

\section{RESULTS AND DISCUSSION}

For 1993 lots, germination percentage ranged from 61 to 98 (Table 1). Germination was less variable in 1994, ranging from 70 to $100 \%$, although mean values were slightly lower. In 1997, germination was 62 to $98 \%$, with mean germination (91\%) higher than the two preceding years.

Electrical conductivity ranged from 70 to 165 $\mu \mathrm{S} \mathrm{cm} \mathrm{cm}^{-1} \mathrm{~g}^{-1}$ in 1993; from 49 to $128 \mu \mathrm{S} \mathrm{cm}^{-1} \mathrm{~g}^{-1}$ in 1994, being similar to that of the previous year; and from 63 to $136 \mu \mathrm{S} \mathrm{cm}^{-1} \mathrm{~g}^{-1}$ in 1997 (Table 1). Accelerated aging (AA) also varied among the test periods, with a mean value of
$72 \%$ for the 54 lots evaluated in 1993, followed by a mean value of $85 \%$ for the 50 lots evaluated in 1994. In 1997, the mean value was the lowest, i.e. 59\% germination after AA (Table 1). The highest values of AA in 1994 were attributed to the narrow range between the highest and the lowest AA values.

In 1993, mean seedling emergence was $69 \%$ for the first sowing time, $63 \%$ for the second, and $82 \%$ for the third (Table 1). In 1994, mean FE was higher than that obtained the previous year, i.e. 87, 79 and $83 \%$ for the first, second and third sowing periods, respectively, reflecting greater homogeneity of environmental conditions at that time. AA varied less in 1994 (79\% to 87\%) than in 1993 (63\% to 82\%). Most 1994 lots concentrated AA between $75 \%$ and $90 \%$, and those with germination close to $100 \%$ presented the best field emergence, above $90 \%$. Consequently, FE was higher in 1994 than in either 1993 or 1997.

In 1997, mean emergence rates for the three sowing seasons were quite similar (Table 1), although AA varied widely in this third year with values ranging from nearly zero to $84 \%$. Most lots concentrated AA between 70 to $84 \%$, with FE higher than $70 \%$. There were significant $(P<0.01)$ correlations between AA results and field emergence (FE) for all years and sowing dates (Table 2).

Table 1 - Evaluation of the physiological potential of soybean seed lots over three years (1993, 1994 and 1997).

\begin{tabular}{|c|c|c|c|}
\hline Tests performed & & Mean & Range \\
\hline \multicolumn{4}{|c|}{1993} \\
\hline Germination $(\%)$ & & 88 & $61-98$ \\
\hline Electrical Conductivity $\left(\mu \mathrm{S} \mathrm{cm}{ }^{-1} \mathrm{~g}^{-1}\right)$ & & 99 & $70-165$ \\
\hline Accelerated Aging $(\%)$ & & 72 & $34-95$ \\
\hline \multirow[t]{4}{*}{ Field Emergence - FE (\%) } & $1^{\text {st }}$ sowing date & 69 & $45-88$ \\
\hline & $2^{\text {nd }}$ sowing date & 63 & $30-80$ \\
\hline & $3^{\text {rd }}$ sowing date & 82 & $61-92$ \\
\hline & Mean (FE) & 71 & $45-87$ \\
\hline \multicolumn{4}{|c|}{1994} \\
\hline Germination $(\%)$ & & 87 & $70-100$ \\
\hline Electrical Conductivity $\left(\mu \mathrm{S} \mathrm{cm}{ }^{-1} \mathrm{~g}^{-1}\right)$ & & 97 & $49-128$ \\
\hline Accelerated Aging (\%) & & 85 & $68-100$ \\
\hline \multirow[t]{4}{*}{ Field Emergence -FE (\%) } & $1^{\text {st }}$ sowing date & 87 & $65-97$ \\
\hline & $2^{\text {nd }}$ sowing date & 79 & $66-92$ \\
\hline & $3^{\text {rd }}$ sowing date & 83 & $69-96$ \\
\hline & Mean $(\mathrm{FE})$ & 83 & $67-95$ \\
\hline \multicolumn{4}{|c|}{1997} \\
\hline Germination $(\%)$ & & 91 & $62-98$ \\
\hline Electrical Conductivity $\left(\mu \mathrm{S} \mathrm{cm}{ }^{-1} \mathrm{~g}^{-1}\right)$ & & 89 & $63-136$ \\
\hline Accelerated Aging $(\%)$ & & 59 & $1-84$ \\
\hline \multirow[t]{4}{*}{ Field Emergence -FE (\%) } & $1^{\text {st }}$ sowing date & 75 & $53-87$ \\
\hline & $2^{\text {nd }}$ sowing date & 77 & $46-91$ \\
\hline & $3^{\text {rd }}$ sowing date & 72 & $34-88$ \\
\hline & Mean $(\mathrm{FE})$ & 75 & $44-89$ \\
\hline
\end{tabular}


Table 2 - Simple linear correlation coefficients $\left(\mathrm{r}^{2}\right)$ among accelerated aging (AA) test results and other tests used to evaluate physiological seed quality (Standard Germination - SG, Electrical Conductivity - EC and Field Emergence - FE), over three years.

\begin{tabular}{|c|c|c|}
\hline Correlations & & Values of $r$ \\
\hline \multicolumn{3}{|c|}{1993} \\
\hline $\mathrm{AA} \times \mathrm{SG}$ & & $0.75 * *$ \\
\hline $\mathrm{AA} \times \mathrm{EC}$ & & $-0.69 * *$ \\
\hline \multirow[t]{3}{*}{$\mathrm{AA} \times \mathrm{FE}$} & $1^{\text {st }}$ sowing & $0.55 * *$ \\
\hline & $2^{\text {nd }}$ sowing & $0.76 * *$ \\
\hline & $3^{\text {rd }}$ sowing & $0.71 * *$ \\
\hline \multicolumn{3}{|c|}{1994} \\
\hline $\mathrm{AA} \times \mathrm{SG}$ & & $0.86 * *$ \\
\hline $\mathrm{AA} \times \mathrm{EC}$ & & $-0.76 * *$ \\
\hline \multirow[t]{3}{*}{$\mathrm{AA} \times \mathrm{FE}$} & $1^{\text {st }}$ sowing & $0.50 * *$ \\
\hline & $2^{\text {nd }}$ sowing & $0.74 * *$ \\
\hline & $3^{\text {rd }}$ sowing & $0.72 * *$ \\
\hline \multicolumn{3}{|c|}{1997} \\
\hline $\mathrm{AA} \times \mathrm{SG}$ & & $0.68 * *$ \\
\hline $\mathrm{AA} \times \mathrm{EC}$ & & $-0.48 * *$ \\
\hline \multirow[t]{3}{*}{$\mathrm{AA} \times \mathrm{FE}$} & $1^{\text {st }}$ sowing & $0.77 * *$ \\
\hline & $2^{\text {nd }}$ sowing & $0.80 * *$ \\
\hline & $3^{\text {rd }}$ sowing & $0.83 * *$ \\
\hline
\end{tabular}

**Significant at $1 \%$

Calculations of the seedling field emergence index (FEI) were based on the germinations test and seed performance in terms of FE. This index was used to characterize the effects of environmental conditions on lot performance for each sowing period (Table 3). Thus, the more adequate the field conditions (moisture, temperature and soil preparation), the greater the similarity of seedling field emergence and germination results, i.e., the higher the FEI. Consequently, ideal FEI is equal or close to 100 .

In this respect, the most severe environmental condition for germination and seedling emergence was obtained in 1993 when FEI = 71 during the second sowing period. The most satisfactory conditions were obtained during the first sowing period of 1994, when identical field emergence and standard germination values were observed resulting in $\mathrm{FEI}=100$.

Table 4 shows the coefficients of determination $\left(r^{2}\right)$ calculated on the basis of field emergence index (FEI) and prediction accuracy (PA). The latter oscillated greatly from 0 to 100, depending on environmental conditions and critical quality levels. A highly significant relation was obtained $\left(r^{2}=90\right)$ when $\mathrm{FE} \geq 80 \%$ and $\mathrm{AA} \geq 90 \%$, despite an absence of data for 1997. When greater field emergence was required ( $\mathrm{FE} \geq 90 \%$ ) and $\mathrm{AA} \geq 70 \%$, FEI
Table 3 - Field emergence index (FEI) for each evaluation and sowing time, based on standard germination test (SG) and seedling field emergence (FE).

\begin{tabular}{lccc}
\hline Sowing time & FE & SG & FEI \\
\hline & \multicolumn{3}{c}{1993} \\
\hline First & 69 & 89 & 78 \\
Second & 63 & 89 & 71 \\
Third & 82 & 89 & 92 \\
\hline & & 1994 & \\
First & 87 & 87 & 100 \\
Second & 79 & 87 & 91 \\
Third & 82 & 87 & 94 \\
\hline & & 1997 & \\
First & 75 & 91 & 82 \\
Second & 77 & 91 & 85 \\
Third & 72 & 91 & 79 \\
\hline
\end{tabular}

below 80 promoted $\mathrm{PA}=0$. The highest field emergence prediction (43\%) was obtained when FEI was equal to 100 . For the critical level of $\mathrm{FE} \geq 90 \%$ and $\mathrm{AA} \geq 80 \%$, slightly higher PA levels were observed; however, FEI below 90 promoted PA values equal to 0 .

Under ideal sowing conditions, seedling field emergence percentage would be almost the same obtained in the standard germination test, and FEI would be equal to or higher than 100 (TeKrony et al., 1987). FEI $=100$ was the rate that best determined how many seed lots performed satisfactorily, with various PA values equal to $100 \%$ at the different requirement levels tested (Table 4). These data agree with those obtained by Egli \& TeKrony (1995; 1996), who observed high PA values only when FEI was close to 100.

PA values for the AA test ranged from zero to $100 \%$ depending on FEI. Thus, it can be emphasized that the assumption of a consistent relationship between laboratory test results and field performance depends on environmental conditions during sowing and seedling emergence.

The best prediction accuracy was achieved within a range of values with AA $\geq 90 \%$, field emergence $\geq$ $80 \%$, and a polynomial regression coefficient $\left(\mathrm{r}^{2}\right)$ of 0.90 . It is possible to guarantee an adequate plant population in the field in this way, since the minimum standard established for soybean seed marketing is $80 \%$ germination

Furthermore, depending on the region, it is also possible to produce soybean seeds with AA values higher than $80 \%$ as long as careful management is adopted during production and processing (TeKrony et al., 1987). Standard germination higher than $95 \%$ is necessary to obtain seed lots with AA $\geq 80 \%$ (Egli \& TeKrony, 1995; 1996). However, from a practical point of view, the same 
Table 4 - Determination coefficient $\left(\mathrm{r}^{2}\right)$ values obtained from field emergence index (FEI) and prediction accuracy, for diverse critical quality levels.

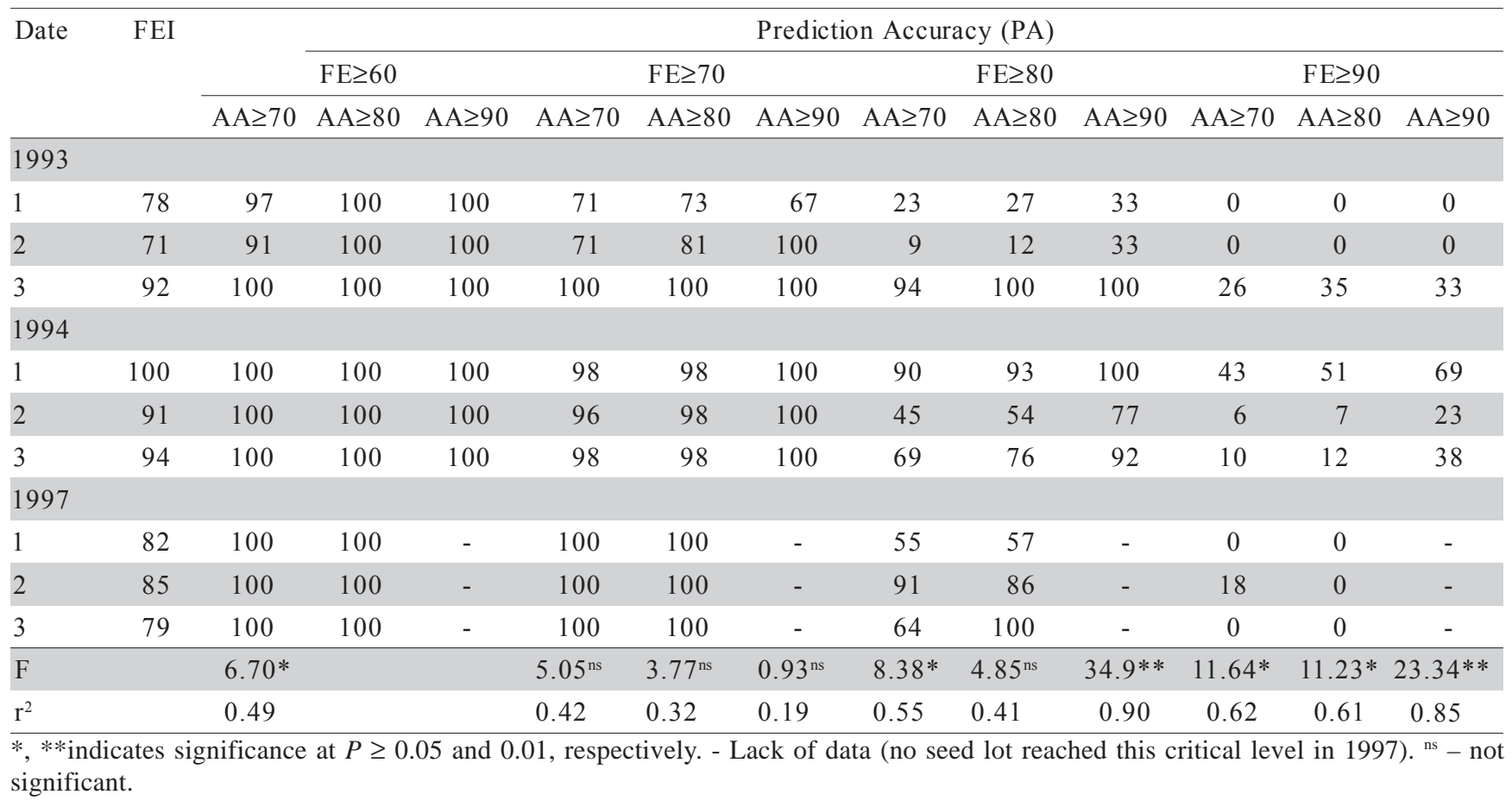

investigators reported that it is very difficult to acquire lots with this level of germination, once seed lots with AA $\geq 80 \%$ occur more frequently. This approach is particularly true for soybean produced under tropical and semi-tropical conditions such as those in Brazil. This observation was confirmed in the present study, in which 32 of the 149 lots evaluated possessed standard germination greater than $95 \%$, whereas 74 lots showed AA $\geq$ $80 \%$. This number increased when the lower AA values of lots from the latest year (1997) were removed. Thus, identification of vigorous lots for sowing based on AA test results can be effective and consistent.

\section{CONCLUSIONS}

The AA test permits a precise estimate of soybean seedling field emergence, although its sensitiveness decreases with less adequate seedbed environmental conditions. The best estimate of field performance was obtained within an AA range $\geq 90 \%$, when prediction accuracy was higher than $80 \%\left(r^{2}=0.90\right)$.

\section{ACKNOWLEDEGEMENTS}

To CNPq for financial support and for a research fellowship granted to the first and second authors.
EGLI, D.B.; TEKRONY, D.M. Soybean seed germination, vigor and field emergence. Seed Science and Technology, v.23, p.595-607, 1995.

EGLI, D.B., TEKRONY, D.M. Seedbed conditions and prediction of field emergence of soybean seed. Journal Production Agriculture, v.9, p.365-370, 1996.

FEHR, W.R., CAVINESS, C.E. Stages on soybean development. Ames: Iowa State University, Cooperative Extention Service, 1977. 11p. (Special Report, 80).

HAMPTON, J.G.; TEKRONY, D.M. Handbook of vigour test methods. 3.ed. Zurich: ISTA, 1995. 117p.

MARCOS FILHO, J. Testes de vigor: Importância e utilização. In: KRZYZANOWSKI, F.C.; VIEIRA, R.D.; FRANÇA-NETO, J.B. (Ed.) Vigor de sementes: Conceitos e testes. Londrina: Abrates, 1999. cap.1, p.1-21.

SPEARS, J.F. An introduction to seed vigour testing. In: VAN DER VENTER, H.A. (Ed.) Seed vigour testing seminar. Zurich: ISTA, 1995. p.1-9.

TEKRONY, D.M.; EGLI, D.B. Relationship between laboratory indices of soybean seed vigor and field emergence. Crop Science, v.17, p.573577, 1977.

TEKRONY, D.M.; EGLI, D.B.; WHITE, G.M. Seed production and technology. In: WILCOX, J. R. (Ed.). Soybeans: improvement, production and uses. 2.ed. Madison: ASA; CSSA; SSSA, 1987. p.295353. (Agronomy Monograph, 16).

VIEIRA, R.D.; KRZYZANOWSKI, F.C. Teste de condutividade elétrica. In: KRZYZANOWSKI, F.C., VIEIRA, R.D., FRANÇA-NETO, J.B. (Ed.) Vigor de sementes: Conceitos e testes. Londrina: Abrates, 1999. cap.4, p.1-26.

YAKLICH, R.W.; KULIK, M.M. Evaluation of vigor tests in soybean seeds: Relationship of the standard germination test, seedling vigor classification, seedling length and tetrazolium staining to field performance. Crop Science, v.19, p.247-252, 1979.

\section{REFERENCES}

BRASIL. Ministério da Agricultura. Regras para análise de sementes. Brasília, 1992. 365p.
Received June 23, 2003

Accepted June 21, 2004 